medRxiv preprint doi: https://doi.org/10.1101/2021.07.19.21260700; this version posted July 22, 2021. The copyright holder for this preprint (which was not certified by peer review) is the author/funder, who has granted medRxiv a license to display the preprint in perpetuity.

\title{
Maternal Urinary Phthalate Metabolites are Associated with Lipidomic Signatures Among Pregnant Women in Puerto Rico
}

Pahriya Ashrap ${ }^{1}$, Max T. Aung ${ }^{2}$, Deborah J. Watkins ${ }^{1}$, Bhramar Mukherjee ${ }^{3}$, Zaira Rosario-Pabón ${ }^{4}$, Carmen M. Vélez-Vega ${ }^{4}$, Akram Alshawabkeh $^{5}$, José F. Cordero ${ }^{6}$, John D. Meeker $^{1 *}$

${ }^{1}$ University of Michigan School of Public Health, Department of Environmental Health Sciences, Ann Arbor, Michigan, United States

${ }^{2}$ University of California, San Francisco, Department of Obstetrics, Gynecology, and Reproductive Sciences, Program on Reproductive Health and the Environment, San Francisco, California, United States

${ }^{3}$ University of Michigan School of Public Health, Department of Biostatistics, Ann Arbor, Michigan, United statues

${ }^{4}$ University of Puerto Rico Graduate School of Public Health, UPR Medical Sciences Campus, San Juan, Puerto Rico

${ }^{5}$ College of Engineering, Northeastern University, Boston, Massachusetts, United statues

${ }^{6}$ Department of Epidemiology and Biostatistics, University of Georgia, Athens, Georgia, United states

*Corresponding author: John D. Meeker, University of Michigan School of Public Health, Department of Environmental Health Sciences, 1415 Washington Heights, Ann Arbor, Michigan 48109, USA, email: meekerj@umich.edu, telephone: 1.734.764.7184 
medRxiv preprint doi: https://doi.org/10.1101/2021.07.19.21260700; this version posted July 22, 2021. The copyright holder for this preprint (which was not certified by peer review) is the author/funder, who has granted medRxiv a license to display the preprint in perpetuity.

All rights reserved. No reuse allowed without permission.

ABSTRACT

Background: Phthalates have been reported to alter circulating lipid concentrations in animals, and investigation of these associations in humans will provide greater understanding of potential mechanisms for health outcomes.

Objective: to explore associations between phthalate metabolite biomarkers and lipidomic profiles among pregnant women $(\mathrm{n}=99)$ in the Puerto Rico PROTECT cohort.

Methods: We measured 19 urinary phthalate metabolites during 24-28 weeks of pregnancy. Lipidomic profiles were identified from plasma samples by liquid chromatography-mass spectrometry-based shotgun lipidomics. Relationships between phthalates and lipid profiles were estimated using compound-by-compound comparisons in multiple linear regression and dimension reduction techniques. We derived sums for each lipid class and sub-class (saturated, monounsaturated, polyunsaturated) which were then regressed on phthalates. Associations were adjusted for false discovery.

Results: After controlling for multiple comparisons, 33 phthalate-lipid associations were identified (q-value $<0.05$ ), and diacylglycerol 40:7 and plasmenyl-phosphatidylcholine 35:1 were the most strongly associated with multiple phthalate metabolites. Metabolites of di-2-ethylhexyl phthalate, bis(2-ethylhexyl) phthalate, dibutyl phthalates, and diisobutyl phthalate were associated with increased ceramides, lysophosphatidylcholines, lysophosphatidylethanolamines, and triacylglycerols, particularly those containing saturated and monounsaturated fatty acid chains.

Significance: Characterization of associations between lipidomic markers and phthalates during pregnancy will yield mechanistic insight for maternal and child health outcomes.

Keywords: Biomarkers; Exposure; Phthalates; Lipidomics; Puerto Rico

Impact Statement: This study leverages emerging technology to evaluate lipidome-wide signatures of phthalate exposure during pregnancy. Circulating lipids are critical for biological processes including inflammation, cell-to-cell communication, and metabolism. Therefore, lipid signatures of phthalate exposure provide insight into potential toxicological mechanisms. Characterization of these mechanisms are relevant for informing the etiology of maternal and children's health outcomes. 
medRxiv preprint doi: https://doi.org/10.1101/2021.07.19.21260700; this version posted July 22, 2021. The copyright holder for this preprint (which was not certified by peer review) is the author/funder, who has granted medRxiv a license to display the preprint in perpetuity.

All rights reserved. No reuse allowed without permission.

\section{INTRODUCTION}

Phthalates are a group of chemicals that are found in numerous commercially available products like food packaging, vinyl flooring, pharmaceuticals, and personal care products [1, 2]. According to biomonitoring reports, human exposure to phthalates is ubiquitous for children and adults [3, 4], including pregnant women and their fetuses due to transplacental passage of phthalates [5]. Prenatal and early-life exposure to phthalates has been related to adverse pregnancy events [6-11] and childhood developmental and cardiometabolic outcomes [12-16].

One of the proposed mechanisms of action and pathways involved in early life phthalateinduced adverse effects is disruption of lipids. Animal studies suggest that phthalates influence circulating lipid levels and lipid signaling [17-20], by interfering with peroxisome-proliferator active receptor gamma $(\operatorname{PPAR} \gamma)[21,22]$. This points to the possibility that a similar mechanism is at play for humans. However, the relationship between prenatal phthalate exposure and lipid metabolism has rarely been investigated among humans. In the limited existing research on humans, the focus has been on the relationship between maternal phthalates and specific lipids such as cholesterol and triglycerides [23-25]. Application of lipidomic profiling (lipidomics) of global cellular lipids in a complex biological sample [26], a branch of metabolomics, may inform research on the discovery of new potential biomarkers of effect or patterns of change related to environmental exposures, including phthalates. Only one study to date has examined the association between maternal metabolomics, including lipid metabolites, and environmental phthalates in pregnant women $(n=115)$ from the Center for the Health Assessment of Mothers and Children of Salinas (CHAMACOS) cohort [27]. The authors found significant relationships between maternal phthalate exposure and plasma free fatty acids, lysolipids, ceramides, and triacylglycerols. 
medRxiv preprint doi: https://doi.org/10.1101/2021.07.19.21260700; this version posted July 22, 2021. The copyright holder for this preprint (which was not certified by peer review) is the author/funder, who has granted medRxiv a license to display the preprint in perpetuity.

All rights reserved. No reuse allowed without permission.

Our previous research in the Puerto Rico PROTECT birth cohort found associations between prenatal phthalate urine metabolite levels and increased odds of preterm birth [28, 29]. In the PROTECT cohort, we also assessed the relationship between maternal lipidomic profiles and

74 adverse birth outcomes and observed numerous significant lipid signatures for spontaneous

75 preterm birth [30]. In the current study, we sought to explore the association between maternal 76 phthalate metabolite biomarkers and lipidomic profiles among pregnant women $(n=99)$ in the

77 PROTECT birth cohort. In doing so, we contribute to the characterization of the potential mechanism of action for phthalate exposure. We also highlight the utility of lipidomics as a tool

79 in environmental epidemiology in detecting intermediate endogenous biomarkers of phthalate exposures.

\section{METHODS}

\section{Study sample}

This study sample is an exploratory subset of the Puerto Rico PROTECT cohort. The

PROTECT cohort began recruitment in 2010 through funding from the National Institute of in the first or second trimester of pregnancy (median 14 weeks gestation). The research protocol was approved by the Ethics and Research Committees of the University of Puerto Rico and

89 participating clinics, the University of Michigan, Northeastern University, and the University of

90 Georgia. Inclusion criteria for recruitment included: participant age between 18 and 40 years;

91 residence in the Northern Karst aquifer region; disuse of oral contraceptives three months before

92 pregnancy; disuse of in vitro fertilization; and no indication of medical records for major

93 obstetrical complications, including pre-existing diabetes. Prenatal spot urine and blood samples

94 were collected during the third study visit at approximately 26 weeks of gestation. From the 
medRxiv preprint doi: https://doi.org/10.1101/2021.07.19.21260700; this version posted July 22, 2021. The copyright holder for this preprint (which was not certified by peer review) is the author/funder, who has granted medRxiv a license to display the preprint in perpetuity.

All rights reserved. No reuse allowed without permission.

95 larger cohort of 2070 pregnant women, we randomly sampled 100 women with the goal of

96 achieving a 1:2 case-control ratio of preterm birth, which included 31 cases and 69 controls. We

97 created and applied inverse probability weights to account for the sampling approach [31].

98

99

100

101

102

103

104

105

106

107

108

109

110

111

112 metabolites comprised mono-2-ethyl-5-carboxypentyl terephthalate (MECPTP) and mono-2-

113 ethyl-5-hydroxyhexyl terephthalate (MEHHTP) [35, 36]. Measured DINCH metabolites were

114 cyclohexane-1,2-dicarboxylic acid monohydroxy isononyl ester (MHiNCH) and cyclohexane-

115 1,2-dicarboxylic acid monocarboxy isooctyl ester $(\mathrm{MCOCH})$ [33]. The sum of di-2-ethylhexyl

116 phthalate metabolites ( $\mathrm{DEHP}$ ) was calculated by adding the molar fractions of MEHP,

117 MEHHP, MEOHP, and MECPP. To achieve unit comparability, $\Sigma$ DEHP (nmol/ml) was 
medRxiv preprint doi: https://doi.org/10.1101/2021.07.19.21260700; this version posted July 22, 2021. The copyright holder for this preprint (which was not certified by peer review) is the author/funder, who has granted medRxiv a license to display the preprint in perpetuity.

All rights reserved. No reuse allowed without permission.

118 multiplied by the molecular weight (MW) of MEHP $(278.348 \mathrm{~g} / \mathrm{mol})$. The resulting units were

$119 \mathrm{ng} / \mathrm{ml}$. Specific gravity (SG) was measured using a handheld digital refractometer (Atago Co.,

120 Ltd., Tokyo, Japan) at the University of Puerto Rico Medical Sciences Campus at the time of

121 sample collection. Values below the limit of detection (LOD) were imputed with the metabolite-

122 specific $\mathrm{LOD} / \sqrt{2}[37]$.

\section{Lipidome measurement}

Plasma lipids were extracted from blood plasma samples provided by women at the third study visit using a modified Bligh-Dyer method [38] using liquid-liquid extraction at room

126 temperature after spiking with internal standards. Analysis of lipids was performed on reversed

127 phase high-performance liquid chromatography (HPLC), followed by mass spectrometry (MS)

128 analysis that alternates between MS and data dependent MS2 scans using dynamic exclusion in

129 both positive and negative polarity and yields excellent separation of all classes of lipids. The

130 lipids are quantified using Multiquant and normalized by internal standards. Measurements are

131 semi-quantitative and are based on the relative abundance of peak intensities. Quality controls

132 (QC) are prepared by pooling equal volumes of each sample, in addition to a well characterized

133 plasma pools, and are injected at the beginning and end of each analysis and after every 10

134 sample injections, to provide a measurement of the system's stability and performance as well as

135 reproducibility of the sample preparation method [39].

137 mass spectral library of 212,516 spectra covering 119,200 compounds from 26 lipid compound

138 classes), by matching the product ions MS/MS data. The method allowed us to measure 587

139 lipids belonging to 19 different lipid classes which include acylcarnitine (AcyICN), ceramides 
medRxiv preprint doi: https://doi.org/10.1101/2021.07.19.21260700; this version posted July 22, 2021. The copyright holder for this preprint (which was not certified by peer review) is the author/funder, who has granted medRxiv a license to display the preprint in perpetuity.

All rights reserved. No reuse allowed without permission.

140 (CER), cholesterol esters (CE), diacylglycerols (DG), glucosylceramides( GlcCer), free fatty

141 acids (FFA), fatty acid esters of hydroxy fatty acids (FAHFA), lysophosphatidylcholine

142 (LysoPC), lysophosphatidylethanolamine (LysoPE), phosphatidic acid (PA),

143 phosphatidylcholine (PC), phosphatidylethanolamine (PE), phosphatidylglycerol (PG),

144 plasmenyl-phosphatidylcholine (PLPC), plasmenyl-phosphatidylethanolamine (PLPE),

145 phosphatidylinositol (PI), phosphatidylserine (PS), sphingomyelin (SM), and triacylglycerol

146 (TG). All individual lipids will be mentioned with the nomenclature as $\mathrm{X}: \mathrm{Y}$, where $\mathrm{X}$ is the

147 length of the carbon chain and $\mathrm{Y}$, the number of double bonds.

\section{Statistical Analysis}

149

Inverse probability weighting of over-representation of preterm birth cases was applied to

151 all statistical analyses presented in this analysis in order for our study to resemble the proportions

152 of preterm birth in a general population [31]. 11 phthalate metabolites (MEHP, MEHHP, MEOHP,

153 MECPP, MBzP, MCOP, MCNP, MCPP, MEP, MBP, MiBP) and the sum of DEHP metabolites

154 ( $\mathrm{DDEHP})$ were included in the statistical analysis. Four phthalate metabolites (MNP, MONP, 155 MHBP, and MHiBP), two DEHTP metabolites (MECPTP, MEHHTP), two DINCH metabolites

156 (MHiNCH, MCOCH) had $>15 \%$ data missing, therefore were excluded from the analysis.

157 The group sum of the individual lipids' relative abundance that belong to each lipid class

$158(\mathrm{n}=19)$ were calculated to evaluate lipid classes. Considering lipid classes containing saturated, 159 mono-unsaturated, and polyunsaturated fatty acids (PUFAs) may present different biological

160 patterns, 45 lipid subgroups (saturated, mono-unsaturated, poly-unsaturated) were created by 161 grouping lipids based on a priori knowledge of lipid class and the number of double bonds in each

162 lipid species. Sum of lipids' relative abundance were also created for the 45 sub-groups.

163 Descriptive statistics for lipids were computed to examine their distributions. Spearman correlation 
medRxiv preprint doi: https://doi.org/10.1101/2021.07.19.21260700; this version posted July 22, 2021. The copyright holder for this preprint (which was not certified by peer review) is the author/funder, who has granted medRxiv a license to display the preprint in perpetuity.

All rights reserved. No reuse allowed without permission.

164 coefficients were calculated between lipid class, lipid sub-groups and phthalates to visualize crude 165 associations.

Multiple statistical strategies were used to assess relationships between lipid profiles and

167 phthalates. The relative abundance of individual lipids, group sums, and sub-groups sums were

$168 \log$-transformed due to their skewed distribution. Subsequently, the log-transformed individual

169 lipids, group sums, and sub-group sums were normalized among individuals (rows) by standard

170 normal variate (SNV) normalization. Covariates were selected based on a priori considerations

171 from literature review of factors that would influence both lipid concentrations and phthalate

172 levels. Multiple linear regression models were fitted to evaluate the association between phthalates

173 and the lipidome, adjusting for maternal age, maternal education, fetal sex, pre-pregnancy BMI,

174 and weight gain during pregnancy. 1) Single pollutant models were performed for each log-

175 transformed and standardized relative abundance of lipid $(n=587)$ regressing on phthalate

176 metabolites $(\mathrm{n}=12)$. False discovery rate (FDR) adjusted $\mathrm{p}$-values (q-values), a commonly used

177 method of adjusting for multiple comparisons in lipidomics studies, were used to account for

178 multiple comparisons. 2) Sums for each lipid class ( $\mathrm{p}=19)$ and lipid sub-group ( $\mathrm{p}=45)$ (saturated,

179 monounsaturated, polyunsaturated were then regressed on each phthalate metabolite $(\mathrm{n}=12)$. The

180 results are presented as estimated percentage changes of lipids, lipid group sums, or sub-group

181 sums with the corresponding 95\% confidence intervals and $p$ values per interquartile range (IQR)

182 change in phthalate metabolite concentration.

183

\section{RESULTS}

185

186

\section{Descriptive statistics}

Demographic and health characteristics of the women in our study are reported in

188 Supplementary Table 1 . The mean age of study participants at the time of enrollment was 26.5 
medRxiv preprint doi: https://doi.org/10.1101/2021.07.19.21260700; this version posted July 22, 2021. The copyright holder for this preprint (which was not certified by peer review) is the author/funder, who has granted medRxiv a license to display the preprint in perpetuity.

All rights reserved. No reuse allowed without permission.

years (standard deviation $=5.7)$. A majority of participants $(77 \%)$ had some level of higher education experience. In this sample, $44 \%$ of participants reported that they were unemployed, and

$19175 \%$ of participant household incomes were below \$50k. Approximately 37\% of participants had

192 pre-pregnancy body mass index of greater than $25 \mathrm{~kg} / \mathrm{m}^{2}$. Most participants did not report smoking

$193 \quad(98 \%)$ or drinking $(92 \%)$ during pregnancy.

\section{Phthalates and Lipidome-wide metabolite associations}

Figure 1 is a Manhattan plot indicating $-\log _{10}(\mathrm{p}$-value) for phthalates in association with

196 individual lipids. The dashed line indicates $\mathrm{p}$ value $=0.001$. The 33 most significant associations

197 after adjusting for false discovery rate ( $p$ value $<0.001$, q value $<0.05$ ) were annotated with the

198 individual lipid in the figure. The Manhattan plot depicts that the lipid metabolites from the DG

199 family were mainly associated with DEHP metabolites, while all of the significant signaling lipids

200 from the CER class were found to be associated with MCNP, MCPP, MBP, and MiBP. Among

201 these top associations, the most prevalent and significant signals were for lipid metabolite DG 40:7

202 in association with all four DEHP metabolites (MEHP, MEHHP, MEOHP, and MECPP), MCPP,

203 and MBP. This was also confirmed on a feature level with a Euler diagram (Supplementary

204 Figure 1) showing the overlap between significant lipid metabolite signals found across different

205 phthalate parent compounds. Among all the lipids with significant signals, DG 40:7 overlapped

206 within most of the ellipses. Another such signal is PLPC 35:1, where MEHHP, MEOHP, MECPP,

207 MBP, and MiBP were significantly associated with this lipid metabolite from the PLPC family. In

208 addition, urinary MECPP and MCPP concentrations were significantly associated with lipid 209 metabolite LysoPE 18:0 from the LysoPE class. MBzP, MCOP, and MEP were not associated with 210 any lipid metabolite in these individual models (Figure 1 \& Supplementary Table 2).

\section{Saturation subgroup associations with pregnancy phenotypes}


medRxiv preprint doi: https://doi.org/10.1101/2021.07.19.21260700; this version posted July 22, 2021. The copyright holder for this preprint (which was not certified by peer review) is the author/funder, who has granted medRxiv a license to display the preprint in perpetuity.

All rights reserved. No reuse allowed without permission.

A list of the individual lipids within each saturation group is reported in Supplementary

213 Table 3. Associations between phthalates and the summation of individual lipid metabolites based

214 on the degree of saturation in fatty acid hydrocarbon tails are presented in Figure 2. Significant

215 associations after false discovery rate correction ( $p$ value $<0.001 \&$ q value $<0.05$ ) were annotated

216 for lipid subclass with color indicating association direction, with red representing a positive

217 association and blue indicating a negative association. The effect estimates and 95\% confidence

218 intervals of the significant associations are also presented in Supplementary Table 4. Nearly all

219 significant associations between phthalates and lipid subgroups were positive. The three oxidative

220 DEHP metabolites, MEHHP, MEOHP, MECPP, as well as the summary measurement $\Sigma$ DEHP

221 were all positively associated with increased saturated CER, saturated and mono-unsaturated

222 LysoPE and PA, and saturated TG. Higher MECPP was additionally associated with mono-

223 unsaturated CER as well as saturated and mono-unsaturated LysoPC.

For increased MCPP concentrations, we observed higher saturated and poly-unsaturated

225 CER, saturated and mono-unsaturated LysoPE, and mono-unsaturated PE levels. The only

226 negative association was found between increased MCPP concentrations and lower saturated FFA.

227 The DBP metabolite MBP was associated with higher levels of saturated CER, PE, and TG, as

228 well as mono-unsaturated CER, PA, and PE. The DiBP metabolite MiBP was associated with

229 higher mono-unsaturated FFA and PA, in addition to saturated CER, PC, and TG. MBzP, MCOP,

230 MCNP, and MEP were not significantly associated with any subgroup lipid class.

231 Whole lipid classes associations with pregnancy phenotypes

The heat map in Figure 3 shows the relationships between phthalate metabolites and lipid

233 classes. Spearman $\rho$ ranged from -0.22 to 0.27 . Correlations between MECPP with LysoPC

$234(\rho=0.27)$ and LysoPE $(\rho=0.25)$ were among the most significant and positive, while the correlation 
medRxiv preprint doi: https://doi.org/10.1101/2021.07.19.21260700; this version posted July 22, 2021. The copyright holder for this preprint (which was not certified by peer review) is the author/funder, who has granted medRxiv a license to display the preprint in perpetuity.

All rights reserved. No reuse allowed without permission.

235 between MEHP and FFA $(\rho=-0.22)$ was the most negative. Figure 4 shows forest plots of the

236 associations between phthalates and whole lipid classes. Among the lipid classes including CER,

237 LysoPC, LysoPE, and TG, we observed the following positive associations (p value $<0.001 \& \mathrm{q}$

238 value $<0.05$ ) with EDEHP (LysoPE), MECPP (CER, LysoPC, LysoPE), MCPP (CER, LysoPE),

239 and MiBP (TG) when clustering all lipid metabolites into their highest level of organization.

240 Supplementary Table 5 lists the effect estimates and 95\% confidence intervals of these

241 associations.

242 DISCUSSION

Using a comprehensive lipidomics platform including almost six hundred lipid species, we

245 explored the associations between phthalates and three hierarchical levels of lipid organization: (1)

246 individual lipidome-wide metabolites, (2) subgroup clustering based on hydrocarbon chain

247 saturation, and (3) whole lipid classes. We found evidence of associations between phthalates and

248 each level of these organizational hierarchies of lipids. At the lipidome-wide level of individual

249 metabolites, biomarkers of exposure to DEHP, MCPP, and MBP were associated with lipid

250 metabolites from the DG family (DG 40:7) and lipids from the CER class. For lipid saturation

251 subgroups, significant positive associations were observed for DEHP exposure biomarkers and

252 saturated CER, mono-unsaturated CER, saturated LysoPC, mono-unsaturated LysoPC, and 253 saturated TG, whereas MECPP was inversely associated with saturated FFA. When we evaluated

254 the broadest level of whole lipid classes, a variety of phthalates are positively associated with CER,

255 LysoPC, LysoPE, and TG lipid classes. The direction of associations indicated that higher

256 concentrations of phthalates were largely associated with increased levels of all of the most

257 strongly associated lipid classes. There was not substantive evidence of associations for phthalates

258 in relation to whole lipid classes such as PA and PE, even though the analysis on the saturation 
medRxiv preprint doi: https://doi.org/10.1101/2021.07.19.21260700; this version posted July 22, 2021. The copyright holder for this preprint (which was not certified by peer review) is the author/funder, who has granted medRxiv a license to display the preprint in perpetuity.

All rights reserved. No reuse allowed without permission.

subgroup level revealed associations with PA and PE lipids containing saturated and monounsaturated fatty acids.

We observed some variation in signatures from lipidome-wide analysis to lipid class 262 analysis, and among distinct DG and PLPC classes. This supports the need to measure the

263 associations between phthalates and lipids at an omics-scale to identify important specific lipid-

264 derived biomarkers of maternal phthalate exposure on lipid disruption that would not be identified 265 with less precise analyses of whole aggregate lipid classes. We generated a list of 20 individual 266 lipids across several classes (DG, CER, LysoPE, PLPC, and FFA) that had robust significant 267 associations after false discovery rate correction and may be used to uniquely characterize the 268 lipidomic responses induced by exposure to different phthalate parent compounds 269 (Supplementary Table 1). Among these lipids, DG 40:7 and PLPC 35:1 were the most 270 significantly associated with exposure to multiple phthalates and may have high predictability for 271 phthalate-induced disruption during pregnancy.

While there is some variation in signatures from lipidome-wide analysis to lipid class 273 analysis, changes to the individual lipidome (represented by PLPC, LysoPE, CER lipids) related 274 to phthalates (DEHP, DBP, and DiBP metabolites) were also observed in the changes of lipid275 class and sub-class level analysis. For lipid classes including CER, LysoPC, LysoPE, and TG, we 276 observed positive associations with $\Sigma$ DEHP (LysoPE), MECPP (CER, LysoPC, LysoPE), MCPP 277 (CER, LysoPE), and MiBP. These increases in lipid classes associated with DEHP metabolite 278 concentrations are consistent with previous reports from animal studies showing that exposure to 279 phthalates, particularly DEHP, influence circulating lipid levels and lipid signaling [17-20, 41]. In 280 contrast, a recent study reported that embryonic exposure to DEHP and DBP in zebrafish 281 significantly reduced the levels of individual lipids from the TG and DG classes [42]. 
medRxiv preprint doi: https://doi.org/10.1101/2021.07.19.21260700; this version posted July 22, 2021. The copyright holder for this preprint (which was not certified by peer review) is the author/funder, who has granted medRxiv a license to display the preprint in perpetuity.

All rights reserved. No reuse allowed without permission.

282 Complementary enrichment analysis using proteomic data revealed biological processes 283 associated with DBP (xenobiotic stimulus, lipoprotein metabolism, lipid catabolism, and 284 regulation of FA and TG catabolism) and DEHP (lipase activity regulation, lipid absorption, lipid 285 catabolism and metabolism) [42]. As noted in the introduction, one suggested mechanism is that 286 phthalates, known as PPAR-agonists, are interfering with peroxisome-proliferator active receptor 287 gamma (PPAR $\gamma)$ and therefore disrupting lipid metabolism [21, 22]. PPAR $\gamma$ is a member of the 288 nuclear receptor superfamily that plays critical physiological roles regulating lipid metabolism [43, 289 44]. It is possible that PPAR $\gamma$ may serve as a mediator for maternal phthalate exposure and 290 disruption of lipids. Previous studies have reported that PPAR $\gamma$ activation can increase both 291 esterification as well as lipolysis [45, 46], which provided evidence for the increased levels of 292 single chain lipid signals in our analysis, including the FFA, DG, and LysoPC, LysoPE families. For lipid saturation subgroups, significant phthalate-induced lipid increases were 294 exclusively observed for several lipid subgroups with saturated and mono-saturated carbon chains and DEHP metabolites (MEHHP, MEOHP, MECPP), MCPP, DBP metabolite (MBP), and DiBP 296 metabolite (MiBP). The significance of the association was particularly related to the saturation of 297 the lipid classes. All of the lipid groups in the above-mentioned associations contain saturated or 298 mono-unsaturated hydrocarbon chains except for the associations between MCPP and poly299 unsaturated CER.-s-Evidence from limited human studies have shown that increased levels of 300 saturated and/or mono-unsaturated lipids can have negative effects on pregnancy and poor birth 301 outcomes [47-49]. Therefore, the positive signals we observed between phthalates and saturated 302 and mono-unsaturated lipid classes may be a proxy mechanism or mediator for suspected adverse 303 effects of phthalates on pregnancy outcomes. On the other hand, the beneficial effects of the poly304 unsaturated fatty acids were widely studied in previous literature [49, 50]. Formal mediation 
medRxiv preprint doi: https://doi.org/10.1101/2021.07.19.21260700; this version posted July 22, 2021. The copyright holder for this preprint (which was not certified by peer review) is the author/funder, who has granted medRxiv a license to display the preprint in perpetuity.

All rights reserved. No reuse allowed without permission.

studies will contribute towards better understanding the potential for poly-unsaturated fatty acids to diminish the toxic effects of phthalates. and DiBP exposure, were associated with increased odds of preterm birth, and urinary metabolites measured later in the pregnancy were more strongly associated with preterm birth [7]. Two other

310 studies in Boston [8] and Mexico City [51] have also reported an association between DBP and

311 DiBP metabolites and spontaneous preterm birth in pregnant women. Changes in the lipid classes

312 such as FFA, CE, DG, and PLPE, have been related to alteration of gestational length in recently 313 published work on the same Puerto Rico cohort [30]. Further, levels of multiple individual lipids

314 and lipid classes (FFA, CER, PA, PE, and TG) were associated with phthalate metabolites MBP

315 and MiBP in the present work. While our findings need to be confirmed, these findings support

316 the hypothesis that disruption of lipid levels may be a possible pathway mediating phthalates and

317 adverse pregnancy outcomes.

318 Our study employed a lipidome-wide analysis in relation to maternal phthalate 319 exposure, while previous studies of the relationship between phthalate concentrations and lipids 320 have been limited to animal studies or studies on targeted lipids such as triglyceride, LDL, and 321 HDL. The extensive repertoire of lipid metabolites that were measured within the maternal 322 lipidome is an important extension of previous research, as this provides an unprecedented 323 opportunity to consider the maternal plasma lipidome in the context of maternal-neonate health.

324 Importantly, this study contributes to the evolving evidence on the disrupting role of phthalates, 325 most notably with DEHP metabolites on lipids, and is among the first to present these associations 326 on a lipidomic scale. 
medRxiv preprint doi: https://doi.org/10.1101/2021.07.19.21260700; this version posted July 22, 2021. The copyright holder for this preprint (which was not certified by peer review) is the author/funder, who has granted medRxiv a license to display the preprint in perpetuity.

All rights reserved. No reuse allowed without permission.

There are a few limitations of this study. The analysis was limited by a fairly small sample

328 size. While the results of this exploratory analysis are biologically plausible and supported by

329 evidence derived from animal studies showing similar results, confirmation in larger diverse

330 cohorts will be required in the future. Because of the cross-sectional nature of the study, windows

331 of vulnerability during pregnancy were not evaluated. Given that phthalate exposure and lipid

332 profiles change across the duration of pregnancy, it is important for future longitudinal studies to

333 evaluate the temporality of the associations between phthalates and maternal lipidome throughout

334 gestation. Although our analyses were adjusted for important potential confounders, residual

335 confounding due to unmeasured variables (e.g., dietary factors) may still exist that could

336 alternatively explain, at least in part, the observed associations.

\section{Conclusions}

338 We employed a semi-targeted lipidomics analysis with more than five hundred measured

339 metabolites in maternal plasma samples, which provided an opportunity to examine the

340 relationship between urine phthalate metabolite concentrations with the plasma lipidome. We

341 reported associations of maternal exposure to DEHP, DOP, DBP, and DiBP on omics scale plasma

342 lipids and lipid classes among pregnant women, particularly with those containing saturated and

343 monounsaturated fatty acid chains. We identified new potential lipidomic markers of phthalate-

344 induced disruption during pregnancy. These results provide new insights into the relationship

345 between maternal phthalate exposure and lipidomic profiles during gestation. 
medRxiv preprint doi: https://doi.org/10.1101/2021.07.19.21260700; this version posted July 22, 2021. The copyright holder for this preprint (which was not certified by peer review) is the author/funder, who has granted medRxiv a license to display the preprint in perpetuity.

\section{Data availability}

Data utilized for this analysis can be obtained by reasonable request by contacting the corresponding author (JDM, meekerj@umich.edu)

\section{Disclaimer}

The findings and conclusions in this report are those of the authors and do not necessarily represent the official position of the NIEHS, EPA, or Centers for Disease Control and Prevention (CDC). Use of trade names is for identification only and does not imply endorsement by the CDC, the Public Health Service, or the US Department of Health and Human Services.

\section{Author Contributions}

P.A.: Statistical analysis; Investigation; Methodology; Writing, review and editing. M.T.A.: Writing, review and editing. D.J.W.: Conceptualization; Funding acquisition. B.M.: Conceptualization; Supervision; Funding acquisition. Z.R.: Data curation; Project administration. C.M.V.: Data curation; Project administration. A.A.: Conceptualization; Funding acquisition. J.F.C.: Conceptualization; Funding acquisition. J.D.M.: Conceptualization; Funding acquisition; Supervision.

\section{Funding}

This study was supported by the Superfund Research Program of the National Institute of Environmental Health Sciences, National Institutes of Health (grants P42ES017198 and). Additional support was provided from NIEHS grant numbers P50ES026049, R01ES032203, and P30ES017885 and the Environmental influences on Child Health Outcomes (ECHO) program grant number UH3OD023251. Support for Max Aung was provided in part by NIH award P30ES030284.

\section{Acknowledgements}

We thank the nurses and research staff who participated in cohort recruitment and follow up, as well as the Federally Qualified Health Centers (FQHC) and clinics in Puerto Rico who facilitated participant recruitment, including Morovis Community Health Center (FQHC), Prymed: Ciales Community Health Center (FQHC), Camuy Health Services, Inc. (FQHC), and the Delta OBGyn (Prenatal Clinic).

\section{Competing Interests}

The authors declare that they have no financial or other conflict of interests. 
medRxiv preprint doi: https://doi.org/10.1101/2021.07.19.21260700; this version posted July 22, 2021. The copyright holder for this preprint (which was not certified by peer review) is the author/funder, who has granted medRxiv a license to display the preprint in perpetuity.

All rights reserved. No reuse allowed without permission.

\section{REFERENCES}

1. Heudorf, U., V. Mersch-Sundermann, and J. Angerer, Phthalates: toxicology and exposure. Int J Hyg Environ Health, 2007. 210(5): p. 623-34.

2. Hauser, R. and A.M. Calafat, Phthalates and human health. Occup Environ Med, 2005. 62(11): p. 806-18.

3. $\quad$ Council, N.R., Phthalates and cumulative risk assessment: the tasks ahead. 2009: National Academies Press.

4. Centers for Disease Control and Prevention (CDC), Fourth National Report on Human Exposure to Environmental Chemicals Updated Tables. 2019.

5. Mose, T., et al., Transplacental transfer of monomethyl phthalate and mono(2-ethylhexyl) phthalate in a human placenta perfusion system. Int J Toxicol, 2007. 26(3): p. 221-9.

6. Casas, M., et al., Exposure to Bisphenol A and Phthalates during Pregnancy and Ultrasound Measures of Fetal Growth in the INMA-Sabadell Cohort. Environ Health Perspect, 2016. 124(4): p. 521-8.

7. Ferguson, K.K., et al., Environmental phthalate exposure and preterm birth in the PROTECT birth cohort. Environ Int, 2019. 132: p. 105099.

8. Ferguson, K.K., T.F. McElrath, and J.D. Meeker, Environmental phthalate exposure and preterm birth. JAMA Pediatr, 2014. 168(1): p. 61-67.

9. Swan, S.H., Environmental phthalate exposure and the odds of preterm birth: an important contribution to environmental reproductive epidemiology. JAMA Pediatr, 2014. 168(1): p. 14-5.

10. Hu, J.M.Y., et al., Associations of prenatal urinary phthalate exposure with preterm birth: the Maternal-Infant Research on Environmental Chemicals (MIREC) Study. Can J Public Health, 2020. 111(3): p. 333-341.

11. Wolff, M.S., et al., Prenatal phenol and phthalate exposures and birth outcomes. Environ Health Perspect, 2008. 116(8): p. 1092-7.

12. Philips, E.M., V.W.V. Jaddoe, and L. Trasande, Effects of early exposure to phthalates and bisphenols on cardiometabolic outcomes in pregnancy and childhood. Reprod Toxicol, 2017. 68: p. 105-118.

13. Kim, S.H. and M.J. Park, Phthalate exposure and childhood obesity. Ann Pediatr Endocrinol Metab, 2014. 19(2): p. 69-75.

14. Bornehag, C.G., et al., Association of Prenatal Phthalate Exposure With Language Development in Early Childhood. JAMA Pediatr, 2018. 172(12): p. 1169-1176.

15. Gascon, M., et al., Prenatal exposure to phthalates and neuropsychological development during childhood. Int J Hyg Environ Health, 2015. 218(6): p. 550-8.

16. Engel, S.M., et al., Prenatal phthalate exposure is associated with childhood behavior and executive functioning. Environ Health Perspect, 2010. 118(4): p. 565-71.

17. Klöting, N., et al., Di-(2-ethylhexyl)-phthalate (DEHP) causes impaired adipocyte function and alters serum metabolites. PLoS one, 2015. 10(12): p. e0143190. 
medRxiv preprint doi: https://doi.org/10.1101/2021.07.19.21260700; this version posted July 22, 2021. The copyright holder for this preprint

(which was not certified by peer review) is the author/funder, who has granted medRxiv a license to display the preprint in perpetuity.

All rights reserved. No reuse allowed without permission.

18. Bastos Sales, L., et al., Analysis of lipid metabolism, immune function, and neurobehavior in adult C57BL/6JxFVB mice after developmental exposure to di (2ethylhexyl) phthalate. Frontiers in endocrinology, 2018. 9: p. 684.

19. Cao, H., et al., Bis-(2-ethylhexyl) Phthalate Increases Insulin Expression and Lipid Levels in Drosophila melanogaster. Basic \& clinical pharmacology \& toxicology, 2016. 119(3): p. 309-316.

20. Bell, F.P., Effects of phthalate esters on lipid metabolism in various tissues, cells and organelles in mammals. Environmental health perspectives, 1982. 45: p. 41-50.

21. Hayashi, Y., et al., Hepatic peroxisome proliferator-activated receptor a may have an important role in the toxic effects of di (2-ethylhexyl) phthalate on offspring of mice. Toxicology, 2011. 289(1): p. 1-10.

22. Shoaito, H., et al., The Role of Peroxisome Proliferator-Activated Receptor Gamma (PPAR $\gamma$ ) in Mono (2-ethylhexyl) Phthalate (MEHP)-Mediated Cytotrophoblast Differentiation. Environmental health perspectives, 2019. 127(2): p. 027003.

23. Perng, W., et al., Exposure to phthalates is associated with lipid profile in peripubertal Mexican youth. Environmental research, 2017. 154: p. 311-317.

24. Allison, K., et al., Prenatal Maternal Phthalate Exposures and Child Lipid and Adipokine Levels at Age Six: A Study from the PROGRESS Cohort of Mexico City. Environmental Research, 2020: p. 110341.

25. Jia, X., et al., Prenatal maternal blood triglyceride and fatty acid levels in relation to exposure to di (2-ethylhexyl) phthalate: a cross-sectional study. Environmental health and preventive medicine, 2015. 20(3): p. 168-178.

26. Han, X. and R.W. Gross, Shotgun lipidomics: electrospray ionization mass spectrometric analysis and quantitation of cellular lipidomes directly from crude extracts of biological samples. Mass spectrometry reviews, 2005. 24(3): p. 367-412.

27. Zhou, M., et al., Metabolomic Markers of Phthalate Exposure in Plasma and Urine of Pregnant Women. Front Public Health, 2018. 6: p. 298.

28. Ferguson, K.K., et al., Environmental phthalate exposure and preterm birth in the PROTECT birth cohort. Environment international, 2019. 132: p. 105099.

29. Meeker, J., et al., Environmental phthalate exposure and preterm birth in the Puerto Rico Testsite for Exploring Contamination Threats (PROTECT) birth cohort. Environmental Epidemiology, 2019. 3: p. 119.

30. Aung, M., et al., Maternal Lipidomic Signatures in Relation to Spontaneous Preterm Birth and Large-For-Gestational Age Neonates. 2021.

31. Richardson, D.B., et al., Analyses of case-control data for additional outcomes. Epidemiology, 2007. 18(4): p. 441-5.

32. Silva, M.J., et al., Quantification of 22 phthalate metabolites in human urine. J Chromatogr B Analyt Technol Biomed Life Sci, 2007. 860(1): p. 106-12.

33. Silva, M.J., et al., Environmental exposure to the plasticizer 1,2-cyclohexane dicarboxylic acid, diisononyl ester (DINCH) in U.S. adults (2000-2012). Environ Res, 2013. 126: p. 159-63.

34. Silva, M.J., et al., Exposure to di-2-ethylhexyl terephthalate in the U.S. general population from the 2015-2016 National Health and Nutrition Examination Survey. Environ Int, 2019. 123: p. 141-147. 
medRxiv preprint doi: https://doi.org/10.1101/2021.07.19.21260700; this version posted July 22, 2021. The copyright holder for this preprint (which was not certified by peer review) is the author/funder, who has granted medRxiv a license to display the preprint in perpetuity. All rights reserved. No reuse allowed without permission.

35. Lessmann, F., et al., Metabolism and urinary excretion kinetics of di(2-ethylhexyl) terephthalate (DEHTP) in three male volunteers after oral dosage. Arch Toxicol, 2016. 90(7): p. 1659-67.

36. Silva, M.J., et al., Identification of di-2-ethylhexyl terephthalate (DEHTP) metabolites using human liver microsomes for biomonitoring applications. Toxicol In Vitro, 2015. 29(4): p. 716-21.

37. Hornung, R.W. and L.D. Reed, Estimation of Average Concentration in the Presence of Nondetectable Values. Applied Occupational and Environmental Hygiene, 1990. 5(1).

38. Bligh, E.G. and W.J. Dyer, A rapid method of total lipid extraction and purification. Canadian journal of biochemistry and physiology, 1959. 37(8): p. 911-917.

39. Gika, H.G., et al., Evaluation of the repeatability of ultra-performance liquid chromatography-TOF-MS for global metabolic profiling of human urine samples. Journal of Chromatography B, 2008. 871(2): p. 299-305.

40. Kind, T., et al., LipidBlast in silico tandem mass spectrometry database for lipid identification. Nature methods, 2013. 10(8): p. 755.

41. Schmidt, J.S., et al., Effects of di(2-ethylhexyl) phthalate (DEHP) on female fertility and adipogenesis in C3H/N mice. Environ Health Perspect, 2012. 120(8): p. 1123-9.

42. $\mathrm{Mu}, \mathrm{X}$., et al., New insights into the mechanism of phthalate-induced developmental effects. Environ Pollut, 2018. 241: p. 674-683.

43. Schoonjans, K., B. Staels, and J. Auwerx, The peroxisome proliferator activated receptors (PPARS) and their effects on lipid metabolism and adipocyte differentiation. Biochim Biophys Acta, 1996. 1302(2): p. 93-109.

44. Latruffe, N. and J. Vamecq, Peroxisome proliferators and peroxisome proliferator activated receptors (PPARs) as regulators of lipid metabolism. Biochimie, 1997. 79(2-3): p. 81-94.

45. Haemmerle, G., et al., ATGL-mediated fat catabolism regulates cardiac mitochondrial function via PPAR-alpha and PGC-1. Nat Med, 2011. 17(9): p. 1076-85.

46. Zechner, R., et al., FAT SIGNALS--lipases and lipolysis in lipid metabolism and signaling. Cell Metab, 2012. 15(3): p. 279-91.

47. Bobinski, R. and M. Mikulska, The ins and outs of maternal-fetal fatty acid metabolism. Acta Biochim Pol, 2015. 62(3): p. 499-507.

48. Ogundipe, E., et al., Peri-conception maternal lipid profiles predict pregnancy outcomes. Prostaglandins Leukot Essent Fatty Acids, 2016. 114: p. 35-43.

49. Khaire, A., et al., Maternal fats and pregnancy complications: Implications for long-term health. Prostaglandins Leukot Essent Fatty Acids, 2020. 157: p. 102098.

50. Wang, Y., et al., Dietary variables and glucose tolerance in pregnancy. Diabetes Care, 2000. 23(4): p. 460-4.

51. Meeker, J.D., et al., Urinary phthalate metabolites in relation to preterm birth in Mexico city. Environ Health Perspect, 2009. 117(10): p. 1587-92. 
medRxiv preprint doi: https://doi.org/10.1101/2021.07.19.21260700; this version posted July 22, 2021. The copyright holder for this preprint (which was not certified by peer review) is the author/funder, who has granted medRxiv a license to display the preprint in perpetuity.

All rights reserved. No reuse allowed without permission.

\section{Figure Legends:}

Figure 1. Manhattan plot showing individual lipids associated with urinary phthalate metabolite concentrations. Models were adjusted for maternal age, maternal education, fetal sex, prepregnancy BMI, and weight gain during pregnancy.

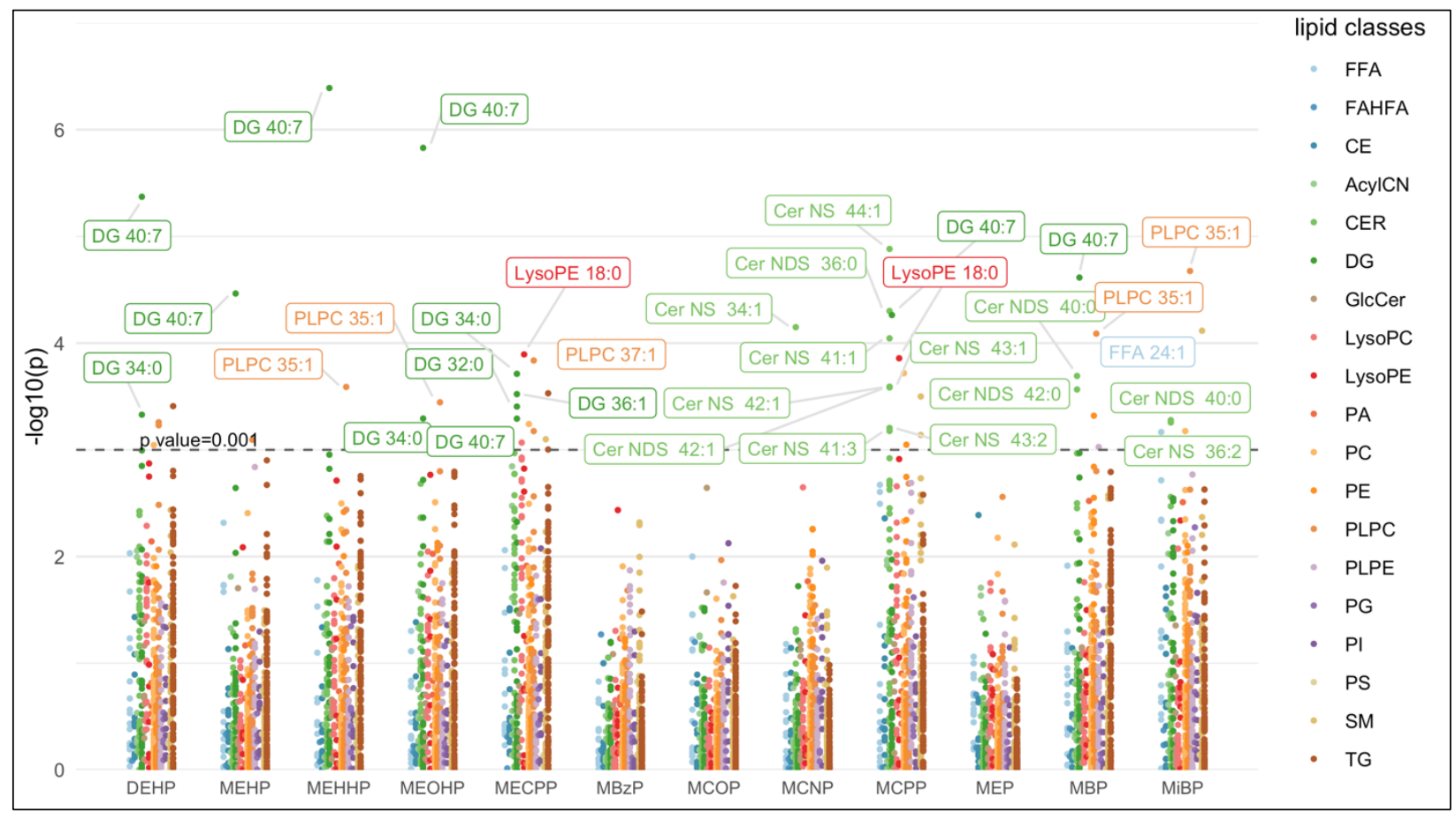


Figure 2. Percent change in lipid subgroup sum z-score associated with urinary phthalate metabolite concentrations. Effect estimates are presented as percent change (\%) for IQR increase in exposure biomarker concentration ${ }^{\mathrm{ab}}$. Models were adjusted for maternal age, maternal education, fetal sex, pre-pregnancy BMI, and weight gain during pregnancy.
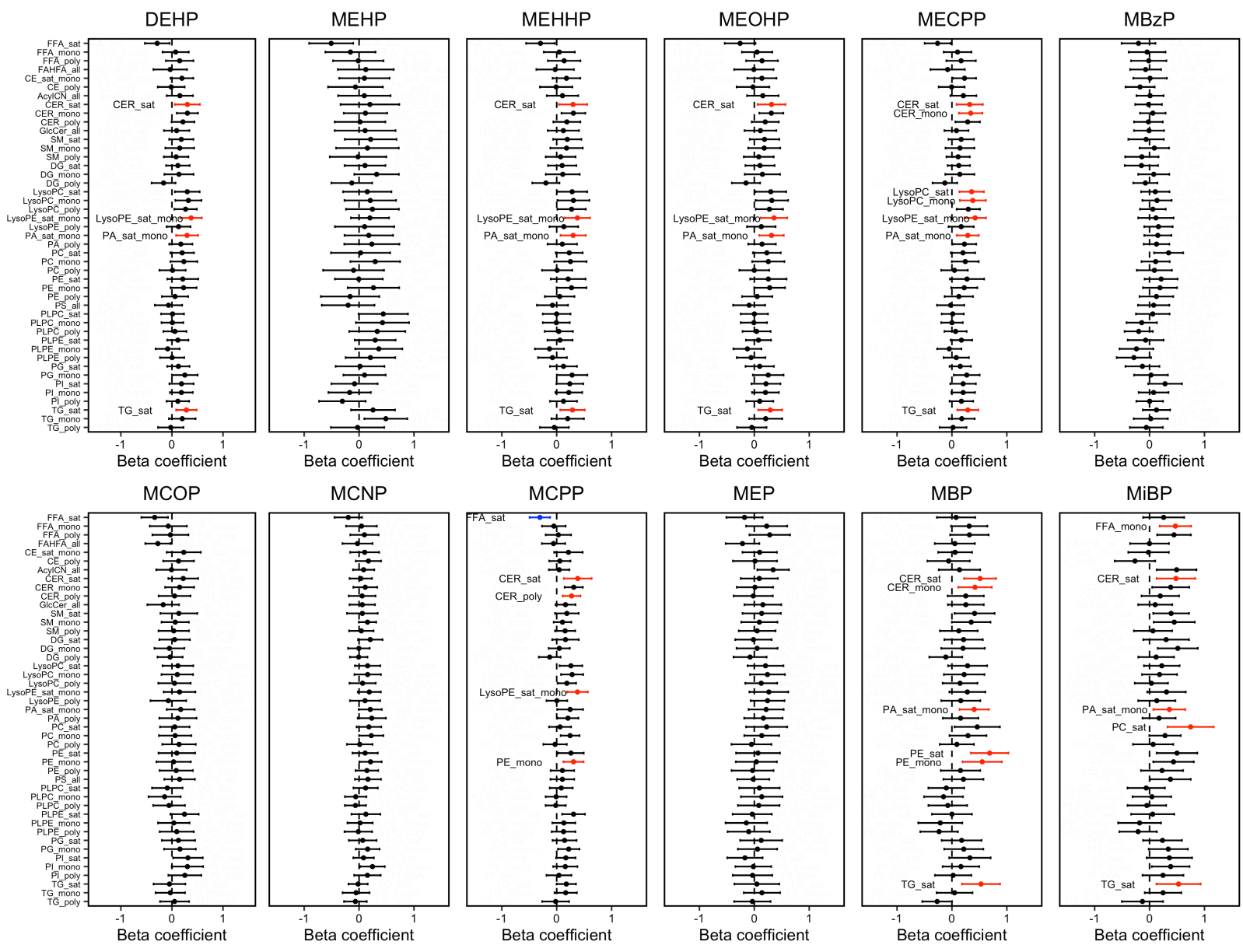
medRxiv preprint doi: https://doi.org/10.1101/2021.07.19.21260700; this version posted July 22, 2021. The copyright holder for this preprint (which was not certified by peer review) is the author/funder, who has granted medRxiv a license to display the preprint in perpetuity. All rights reserved. No reuse allowed without permission.

Figure 3. Correlation matrix between specific gravity corrected concentrations of phthalate metabolites and all lipid classes

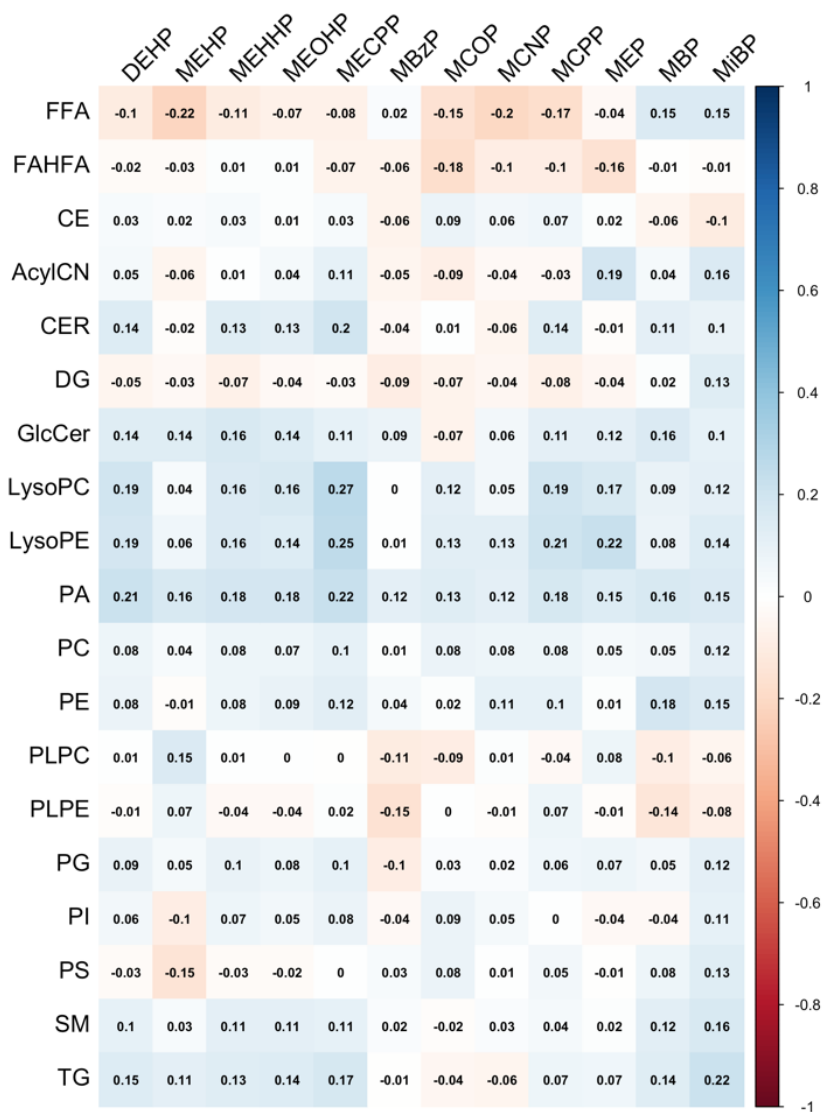


Figure 4. Percent change in lipid class sum z-score associated with urinary phthalate metabolite concentrations. Effect estimates are presented as percent change (\%) for IQR increase in exposure biomarker concentration $^{\mathrm{ab}}$. Models were adjusted for maternal age, maternal education, fetal sex, pre-pregnancy BMI, and weight gain during pregnancy.
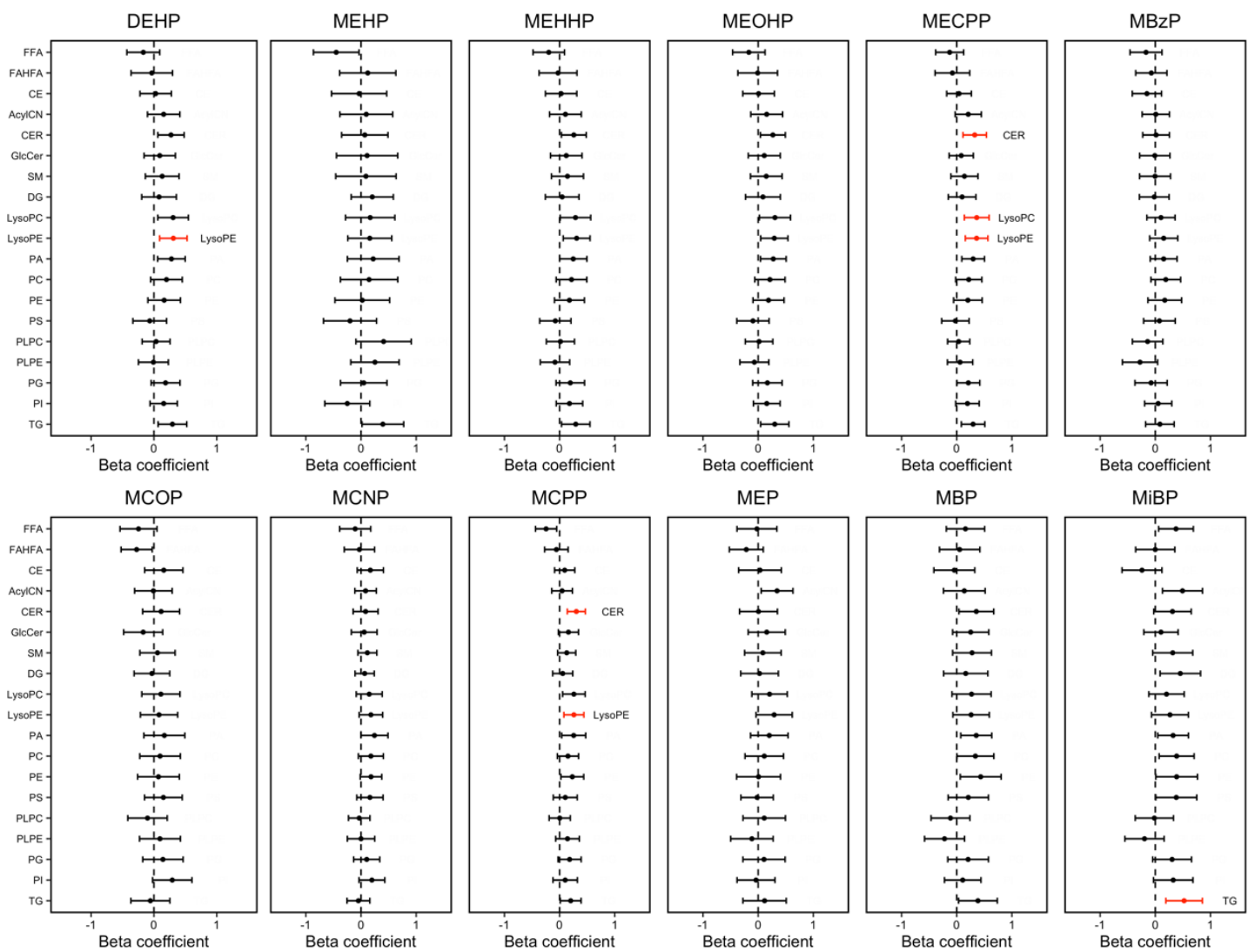